\title{
Role of Credibility of Phenomena in Attitude toward Advertising
}

\author{
Deneçli C. ${ }^{1}$ \\ Deneçli S. ${ }^{2}$
}

${ }^{1}$ Ceyda DENEÇLI, Nişantaşı University, (Turkey)

e-mail: ceyda.denecli@nisantasi.edu.tr

2 Sevda DENEÇLI, Nişantaşı University, (Turkey)

e-mail: sevda.denecli@nisantasi.edu.tr

\begin{abstract}
Having a huge transformation in conjunction with transition from Web 1.0 to Web 2.0, the Internet gave rise to emergence of micro-celebrities called phenomena and led the concept of influencer marketing which uses these celebrities as the basic decision makers to gain popularity among today's marketing activities. Many studies reveal that the phenomena (influencers) acting as "senders" in online marketing activities influence their followers and activate them in desired direction. In the present study conducted in this direction, the impact of the credibility, attractiveness, expertise and trustworthiness of the phenomena on the attitude toward advertising was examined. The research was done on university students. The correlation analysis made in the study to reveal if there is a significant correlation between the credibility dimensions of attractiveness, expertise and trustworthiness of the phenomena and the attitude toward advertising shows that there are significant correlations between all three dimensions and attitude toward advertising $(r=0.46, p<0.01$ for attractiveness; $r=0.26 ; p<0,01$ for expertise; $r=0.31 ; p<0,01$ for trustworthiness). Furthermore, the results of the research show that only the attractiveness dimension of the phenomena among their credibility dimensions (attractiveness, expertise, trustworthiness) has a significant impact on the attitude toward advertising.
\end{abstract}

Keywords: Phenomenon, Social Media, Attitude toward Advertising.

\section{Introduction}

Dating back to 1950s, the Internet has an indispensable place in our life every passing day with the changes it had. Generation of systems, which allow the users create contents in conjunction with transition to Web 2.0, has made the Internet open to interaction (Bilgici Oğuz and Atasoy Aktaş, 2018:83). This transformation of the Internet has made the users active and converted the face-toface, word-of-mouth communication regarding a product or brand into online communication (Charlesworth, 2015:113). The word-of-mouth (WOM) which was defined as electronic word-of-mouth (e-WOM) in virtual reality environment can also be defined as positive or negative comments of current, past or potential customers about a product, brand or institution made via Internet (Cheung, Lee \& Rabjohn, 2008:230-231).

In conjunction with emergence of social media, e-WOM has become a prevalent and effective source of information (Thoumrungroje, 2014:9), and it is now seen as a power influencing the purchasing decisions of individuals (Thurau, Gwinner \& Gremler, 2002:232), as the personal sources composed of relatives, friends and acquaintances are regarded more trustworthy in contrast with impersonal sources such as television, magazines and so forth (Shimp, 2007:180). Individuals who want to experience the products but cannot find the opportunity to do so, would like to hear the advices of the individuals who have already experienced the products in question (Cakim, 2010:6). In this context, mouth-of-word communication has a great influence on formation of the judgment and attitude regarding a product and decision-making process (Brown, Broderick \& Lee, 2007:15).

Social media is an electronic environment that enables the individuals share contents such as 
information, opinions, personal messages, comments, videos and images, the social media (White, 2012:9) and also gives an opportunity to reach many people simultaneously as it is a platform that enables online communication as opposed to traditional ways of communication (Coles, 2015:4).

Composed by individuals having common fields of interest, similar perspectives and backgrounds, social networks are regarded as online platforms that support the communication between individuals who share their personal or professional interests, activities or experiences (Bregman, 2014: 6) and enable them to connect with each other to form a network. Subscribers of social networks like Instagram, Twitter, Facebook and Linkedln under various names such as followers, friends and connections provide flow of information with their sharings (White, 2012:56).

The websites included in social networks enable the consumers to propagate information and opinions about the products they have used or experienced and provide opportunity to obtain valuable information with regard to marketing (Schindler \& Bickart, 2005:35). Katz, Lazarsfeld et al. have shown that the communication in the websites included in social networks where consumers share information by interacting with each other is established in the form of two-step flow, where the information first flows from mass media to opinion leaders and then from opinion leaders to receivers (Nisbet \& Kotcher, 2009:329).

\section{Literature}

The influencer marketing, which is defined as an application to determine the primary decision-makers among the target audience and mostly preferred by the marketing performers of today refers to using the influence of these primary decision-makers on people and encourage them to perform WOM (Jaakonmäki, Müller \& Brocke, 2017:1153). These primary decision-makers called the phenomena act as independent approvers who shape the attitudes of their followers by using the social media (Freberg, Graham, McGaughey \& Freberg, 2011:90). They play an active role in marketing process by creating branded contents, promoting the brands and recommending them to their followers for a certain fee paid by the companies (Lou \& Yuan, 2019:58).

The phenomena who act as opinion leaders in Internet environment where individuals have the opportunity to obtain various and intensive information about brands from other individuals with whom they have little or no previous relationship or have no mutual acquaintances (Schindler \& Bickart, 2005:37) share information in social network sites by interacting with their followers (Lin, Bruning \& Swarna, 2018: 432).

In his book titled "The Presentation of Self in Everyday Life" (1956) Goffman states that the identity of individuals is an "ongoing performance", the life is a stage and the individuals present themselves and what they do differently as artists to manage the impressions of others about themselves. Marshall mentions the evolving of the performance referred by Goffman as presentation of identity and self in today's online environment and argues that social networking sites are today's "stages" and individuals deliver their performances with their profiles, the images they share and their messages (Marshall, 2010:40). On the other hand Giddens (1991) who defines the identity as a worked-on "project" related to life style (1991) states that routine practices of individuals like dressing styles, eating habits and so forth are not only related to meeting utilitarian needs but they are also used to materialize a certain narrative with regard to self-identity.

Individuals want to manage how others perceive them so they can be known the way they want to be known. Accordingly, the individuals share everything about them like the way they speak, their tone of voice, habits, fields of interest and so forth in line with the identity they wish to create, under their control and to the extent they want to present themselves to others (Deckers \& Lacy, 2010:7). Thereby the online identity of individuals is built in line with what they share online and interpretation of these sharings by other individuals with whom they interact online (Good, 2012:560; Senft, 2013:348).

The personal branding that emerges as a result of the strategic creation process of the identity to be introduced to others (Marwick, 2013:166) includes the individuals who develop a dioristic public 
image for gaining profit and/or a cultural capital (Khamis, Ang \& Welling, 2017:191). In other words, a branded personality is the reflection of make-believe "realities" of an individual (Hearn \& Schoenhoff, 2016:202) and a character generated for public consumption (Hearn, 2008:201).

Transition from publication to participatory media has enabled the individuals to create the identities they want through social media, develop personal branding, added a new dimension to the concept of fame (Marwick, 2016:333-334) and introduced the concept of micro-celebrity. Micro celebrities are also defined as digital celebrities or online social media phenomena (Mikuláš \& Chalányová, 2017:68). The micro celebrities who are actually "ordinary persons" earned a reputation on the Internet due to their sharings on social media platforms like Instagram and Twitter (Driessens, 2016:378) form a new online performance style that includes increasing the popularity of some persons on the Web by way of using technologies such as video sharing sites, blogs and social networking sites (Senft, 2008:25).

The number of likes, sharings, followers and comments determines success of a micro celebrity. For micro celebrities, larger audience means a more powerful brand. Micro celebrities have to establish a more real and warmer relationship with their followers than the mainstream media stars establish with their fans (Khamis, Ang \& Welling, 2017:196-197).

As the persons who have gained reputation in traditional media can expand the awareness of consumers regarding the advertisement of a company and develop an attitude toward company's image and the brand (Solomon, Bamossy, Askegaard \& Hogg, 2013:316), it can be said that the social media phenomena who are micro celebrities may similarly ensure the consumers to develop an attitude toward both the advertisement and the company.

The concept of attitude is defined as the assessments of people for objects and ideas. These assessments are learned over time and consequently, may vary from person to person (JanssonBoyd, 2010:82). Formation of consumer attitude is influenced by their personal experiences, family and friends, direct marketing and mass media to a large extent. Formation of consumer attitude toward products and services is based on their trials and assessments of those products and services. When consumers try a product or brand and like it, they may develop a positive attitude toward the product or the brand and purchase it again later. Consequently, marketers try to make the consumer try and evaluate the products and brands. On the other hand, interaction of consumers with their families and close friends makes them develop some attitudes that may affect their lives (Schiffman, Kanuk \& Hansen, 2011:244).

Attitude toward advertising, on the other hand, is defined as the tendency to respond positively or negatively to a certain advertising stimulus when the consumers are exposed to it for a certain period of time. Advertisements may arouse numerous emotional responses from disgust to happiness. Moreover, studies have revealed that emotional responses towards ads may vary from a group of consumers to another (Solomon, Bamossy, Askegaard \& Hogg, 2013:298).

While the first studies conducted on advertising have addressed the favorability of ads, later studies have dealt with the relationship and connection of consumers' belief in ads with the attitude developed towards advertising. These studies reveal that consumers may develop different attitudes towards advertising such as doubt, accusation, fun and appreciation. While some people regard ads as sources of useful information and entertainment, some others qualify them as hidden sources of manipulation (Nelson, Keum \& Yaros, 2004:4).

When it is considered that attitudes allow prediction of behaviors and even may direct them, attitude is the target of persuasion (Gao, 2005:828). "Source credibility" which is defined as "ethos" and argued by Aristoteles as being the most powerful tool of persuasion still plays a vital role in the communication process (McCroskey \& Young,1981:24). Source credibility has a great influence on thoughts of individuals. The high credibility of a source makes the message more persuasive for the individual while the low credibility of the source reduces the persuasiveness of the message when the individual resist defending the message (Harmon \& Coney, 1982:255).

When the literature is reviewed, there are many studies about the source credibility. While some studies address source credibility as perceived expertise and trustworthiness (Hovland, Janis \& 
Kelley, 1953:21), Ohanian (1990) has added attractiveness dimension to expertise and trustworthiness dimensions and addressed the source credibility under three dimensions. In his study, he defines the source credibility as a term used to imply the positive properties that influence acceptance of the conveyed message by the recipient.

Trustworthiness dimension of credibility is defined as the belief of people in the source in respect of providing the information in an objective, honest and sincere manner (La Ferle \& Choi, 2005:70). While the trusted sources are perceived by individuals as honest and sincere, untrusted sources are the people about whom the individuals have doubts (Priester \& Petty, 2003:408). Expertise of the source, the second dimension of credibility, is the ability of the celebrity to provide accurate and useful information to consumers (Pikas, Schied \& Pikas, 2012:43). Attractiveness of the source, the third dimension of credibility refers to the perceived social value of the source. This quality may arise from the physical appearance, personality, social status of the person or resemblance of the source to recipient (Solomon, Bamossy, Askegaard \& Hogg, 2013:316).

Sometimes consumers regard the person who delivers the message as the source of the message. As the source acting in the advertisement and conveying the message of the ads to consumers has a great effect on the credibility of the message, it is seen that many big companies use social media phenomena who create the form of "celebrity" capital due to their sharings through social networks as "ethos" to introduce their products and persuade the target audience (Hearn \& Schoenhoff, 2016:194; Schiffman, Kanuk \& Hansen, 2011:271).

\section{Research}

The aim of this study is revealing whether the attractiveness, expertise and trustworthiness dimensions of the credibility of the phenomena ${ }^{1}$ serving as sources on social media have an impact on the attitudes of individuals towards advertising or not.

In this context, the following hypotheses were developed to test within the scope of the research by benefiting from studies conducted on credibility of source and attitude toward advertising (Ameline \& Zhu, 2016; Lee, Haley \& Yang, 2013; Kim, Haley \& Koo, 2009; Ohanian, 1990).

H1: (a) Attractiveness dimension, (b) expertise dimension, (c) trustworthiness dimension of finding the phenomena credible has an impact on individuals' attitudes towards advertising.

\section{Participants}

Participants of the research were asked if there is a phenomenon on social media who they follow and if there are any, what are their fields. Answers of participants who do not follow any phenomenon were excluded from the scope of the research and not included in the analyses. The research was made on 345 students studying communication in Istanbul Kultur University and Nisantasi University in Istanbul province in November 2018. However, 27 students have stated that they don't follow any phenomenon and their questionnaires were excluded and the analyses were made in consideration of the answers of 318 participants.

\footnotetext{
${ }^{1}$ Micro celebrities known as social media influencers are called phenomenon in Turkey. Therefore, the social media influencers are referred to as phenomena in the research section of this study.
} 
$54 \%$ of the participants were females and $39 \%$ were in $20-21$ age range (Table 1 ).

\begin{tabular}{|l|l|l|l|}
\hline \multicolumn{2}{|l|}{ Demographic Variables } & Frequency & Percentage \\
\hline Gender & Male & 145 & 46 \\
\hline & Female & 173 & 54 \\
\hline Age & $18-19$ & 86 & 27 \\
\hline & $20-21$ & 123 & 39 \\
\hline & $22-23$ & 98 & 31 \\
\hline & 24 and above & 11 & 3 \\
\hline
\end{tabular}

\section{Data Collection Tool}

Table 1: Demographic Data

Questionnaire method was used to collect data in the research. The questionnaire form used in the research includes three parts. The questions included in the first part of the questionnaire form were intended to understand if the participants have social media accounts, if they have Instagram accounts, how frequently they log in to social media, if they follow any phenomenon and if there is, the fields of the phenomena they follow. Then they were asked to answer other questions by considering their favorite phenomenon. In the second part of the questionnaire form a scale was used to measure the credibility of the phenomena for participants and another scale was used to measure their attitude toward advertising. The last part of the questionnaire included demographic questions.

The scale used in the research to measure the degree of the credibility of phenomena for participants was developed by Ohanian (1990). The scale was developed as a semantic differential scale to measure the attractiveness, expertise and trustworthiness dimensions and expressions in the study were arranged in the form of a five-point Likert scale. The scale includes 3 dimensions; (a) attractiveness dimension (b) expertise dimension, and (c) trustworthiness dimension. The scale includes 15 expressions in total, which are arranged in five-point Likert scale (5: strongly agree, 1: strongly disagree). There are 5 expressions under the attractiveness dimensions in the scale (sample expression: "I consider the phenomenon I follow attractive). The expertise dimension in the scale has five expressions (sample expression: I consider the phenomenon I follow as an expert in his/her field). The trustworthiness dimension also has 5 expressions (sample expression: I consider the phenomenon I follow as honest). Scoring high points in the scale indicates that the participant has made a positive assessment in the related dimension and scoring low points indicates the exact opposite. The result of the factor analysis made for the scale confirms that the scale is composed of three dimensions (Kaiser-Meyer-Olkin $=0.87$ Bartlett Test $p<0.01$ ). The Cronbach Alpha values calculated for the scale (varying between 0.89 and 0.92 ) indicates that the scale has internal consistency $(\alpha>0.60)$.

The scale developed by Lee (2000) and adapted by Kim, Haley \& Koo (2009) was used in the research to assess the level of attitudes of the participants towards advertising. The scale was in the form of five-point Likert scale (5: strongly agree, 1: strongly disagree) and included 4 expressions (sample expressions: "The advertisement made by the phenomenon I follow is appealing to me", "I like the advertisement made by the phenomenon I follow"). Accordingly, scoring high points in the scale indicates that the person has developed an attitude toward the ad made by the phenomenon he/she follows and scoring low points indicates the exact opposite. The result of the factor analysis made for the scale confirms that the scale is composed of one dimension (Kaiser-Meyer-Olkin $=0.83$ Bartlett Test $p<0.01$ ). The Cronbach Alpha values calculated for the scale is 0.91 and it indicates that the scale has internal consistency. 


\section{Statistical Analyses}

Factor analysis was used in the research to determine the construct validity of the scales used to measure the participants' finding the phenomena credible and their attitudes towards advertising and Cronbach Alpha was used to determine their reliability.

As the data set should have a normal distribution to perform the parametric tests, the data were tested to see if they have a normal distribution or not. Skewness and kurtosis values were examined for normality test. If the skewness-kurtosis value is in the range of $+3,-3$, it indicates that the data are distributed normally (Kline, 2011:60-62). In this context, the skewness values of the observed variables of the research model tested in the study were found in the range of $-1,194-0,84$ and kurtosis value were found in the range of -1,155-1.234 and normality was determined. Accordingly, the analyses were made with parametric tests.

In the study, whether the results obtained from the attitude toward advertising showed differences according to the demographic characteristics of the participants was tested with z-test, which was used to determine the difference between the averages of the two groups in the two categorical variables. As the number of the analyzed data was more than 30 , z-test was used instead of t-test (Bowen \& Starr, 1994:372).

A correlation analysis was performed in the research to determine the relationship between finding the phenomena credible and level of attitude toward advertising. In addition, a multiple regression analysis was performed to determine which one or ones of the attractiveness, expertise and trustworthiness dimensions under the credibility of the phenomena is/are effective on participants' attitude toward advertising.

\section{Findings}

The data regarding the fields of the phenomena followed by participants are given in the below table. However, the participants who follow more than one phenomenon have ticked more than one choice (Table 2).

\begin{tabular}{|l|l|}
\hline Field & Frequency \\
\hline Entertainment & 152 \\
\hline Travel & 94 \\
\hline Fashion & 86 \\
\hline Arts & 73 \\
\hline Beauty-Care & 72 \\
\hline Life Style & 71 \\
\hline Photography & 63 \\
\hline Food-drink & 59 \\
\hline Other & 38 \\
\hline
\end{tabular}

Table 2: Fields of the Phenomena Followed by Participants

According to the result obtained in the research with regard to assessment of the credibility of the phenomena by consumers (Table 3), it is seen that the consumers participated in the research evaluate the phenomena as somewhat positively in terms of attractiveness, expertise and trustworthiness dimensions (attractiveness dimension $\mathrm{O}=3,10$; expertise dimension $\mathrm{O}=3,71$; trustworthiness dimension $\mathrm{O}=3,28$ ).

On the other hand, when the attitudes of the participants towards advertising are evaluated, it was determined that their attitude toward advertising $(O=2,75)$ was partially positive. 


\begin{tabular}{|l|l|l|l|l|l|l|}
\hline & 0 & SS & $(1)$ & $(2)$ & $(3)$ & $(4)$ \\
\hline (1) Attitude toward Advertising & 2,75 & 1,14 & 1 & & & \\
\hline (2) Attractiveness & 3,10 & 1,10 & $0,46^{\star *}$ & 1 & & \\
\hline (3) Expertise & 3,71 & 0,96 & $0,26^{\star *}$ & $0,27^{\star *}$ & 1 & \\
\hline (4) Trustworthiness & 3,28 & 0,99 & $0,31^{* *}$ & $0,38^{* *}$ & $0,60^{\star *}$ & 1 \\
\hline
\end{tabular}

${ }^{* *} p<0,01$

Table 3: Average and Standard Deviation Values Obtained from the Scales and Results of the Correlation Analysis

A correlation analysis was performed to examine the relationship between the credibility assessments of participants regarding the phenomena and their attitude toward the advertisement made by the phenomena they follow. According to the results of the correlation analysis (Table 3), it is seen that there is a significant relationship between attractiveness, expertise and trustworthiness dimensions used to measure the assessments regarding the credibility of the phenomena and the level of attitude of participants towards advertising. It is found out that there is a positive directional middle level relationship between the attitude toward advertising and attractiveness dimension of the credibility of the phenomena $(0,40<r<0,70)$, and a positive directional low level relationship with expertise and trustworthiness dimensions $(r<0,40)$. Accordingly, as the credibility of the phenomena increases positively on attractiveness, expertise and trustworthiness dimensions for participants, their attitude toward advertising also increases positively. In other words, as the participants increasingly find the phenomena well-dressed, beautiful/handsome, sophisticated, experienced, talented and qualified and find them trustable, honest, credible, keeping their words, their attitude toward advertising also increases positively.

The approaches of participants to the credibility of the phenomena and their attitude toward advertising were analyzed to see if they differ by gender. As the gender variable has two categories, difference between the categories was analyzed with z-test (The value in z/F column of the table is the $\mathrm{t}$-value). According to the results of the analysis (Table 4), the attractiveness dimension of the credibility of the phenomena shows a significant difference by gender, and expertise and trustworthiness dimensions of the credibility of the phenomena and attitude toward advertising do not show a significant difference by gender. Accordingly, it is seen that females assess the phenomena more positively than males on attractiveness dimension.

\begin{tabular}{|l|l|l|l|l|l|l|}
\hline \multirow{2}{*}{ Demographic Variables } & $\mathrm{N}$ & $\mathrm{O}$ & $\mathrm{SS}$ & $\mathrm{z} / \mathrm{F}$ & $\mathrm{p}$ \\
\hline \multirow{2}{*}{ Attractiveness } & Male & 145 & 2,76 & 1,12 & \multirow{2}{*}{$-5,15$} & \multirow{2}{*}{$0,00^{\text {** }}$} \\
\cline { 2 - 5 } & Female & 173 & 3,38 & 1.00 & & \\
\hline \multirow{2}{*}{ Expertise } & Male & 145 & 3,81 & 0,97 & \multirow{2}{*}{1,54} & \multirow{2}{*}{0,13} \\
\cline { 2 - 5 } & Female & 173 & 3,64 & 0,96 & & \\
\hline \multirow{2}{*}{$\begin{array}{l}\text { Attitude toward } \\
\text { Advertising }\end{array}$} & Male & 145 & 3,33 & 1,08 & \multirow{2}{*}{0,65} & \multirow{2}{*}{0,52} \\
\cline { 2 - 5 } & Female & 173 & 3,25 & 0,92 & & \\
\cline { 2 - 5 } & Female & 145 & 2,56 & 1,12 & \multirow{2}{*}{$-2,71$} & \multirow{2}{*}{0,01} \\
\hline \multirow{2}{*}{${ }^{* *} \mathrm{p}<0,01$} & 173 & 2,90 & 1,14 & & \\
\hline
\end{tabular}

Table 4: Differences in the creditibility of the phenomana for participants and their attitude toward advertising by gender 
On the other hand, whether the credibility of the phenomena for participants and their attitude toward advertising differ by age variable or not was not analyzed, as the age ranges in the research were so close to each other.

As a result of the regression analysis performed to determine the impact of finding the phenomena credible on the attitude toward advertising (Table 5), a significant model was obtained $(R=0,49 R 2=0,24 F=32,53 \quad p=0,00<0,01)$. It is seen that the variables in the model explains $24 \%$ of the change in the attitude toward advertising. It was determined that the attractiveness dimension of the credibility of the phenomena in the model has a significant impact of the attitude toward advertising (Standard Beta $=0,309 p=0,00<0,01$ ). On the other hand, it is seen that expertise and trustworthiness dimensions of the credibility of the phenomena do not have a significant impact on the attitude toward advertising (hypothesis a is accepted, b and c are rejected). In this context, as the positive assessment by participants on attractiveness dimension increases, attitude toward advertising will also be more positive. In other words, finding the phenomena elegant, well-dressed, beautiful/handsome will increase their positive attitude toward advertising.

\begin{tabular}{|l|l|l|l|l|l|}
\hline & $\mathrm{B}$ & $\begin{array}{l}\text { Standard } \\
\text { Error }\end{array}$ & $\begin{array}{l}\text { Standard } \\
\text { Beta }\end{array}$ & $\mathrm{t}$ & $\mathrm{P}$ \\
\hline (Constant) & 0,68 & 0,25 & & 2,72 & $0,01^{* *}$ \\
\hline Attractiveness & 0,41 & 0,06 & 0,39 & 7,38 & $0,00^{* *}$ \\
\hline Expertise & 0,12 & 0,07 & 0,10 & 1,62 & 0,11 \\
\hline Trustworthiness & 0,11 & 0,07 & 0,10 & 1,51 & 0,13 \\
\hline
\end{tabular}

Dependent Variable: Attitude toward Advertising

$R=0,49 R 2=0,24 F=32,53 p=0,00<0,01$

${ }^{* *} \mathrm{p}<0,01$

\section{Table 5: Results of Regression Analysis Related to the Impact of Approaches to Credibility of the Phenomena on Attitudes toward Advertising}

\section{Conclusion}

Rapid development of the Internet every passing day has made it inevitable for marketing performers to carry over their marketing activities to Internet environment. In conjunction with transition to Web 2.0, the Internet has activated the users by enabling them to write messages, make comments, share videos and images etc. The passive users of the past have become co-creators of contents today and begun playing an important role in the communication process on the Internet.

The users who become branded individuals due to their online identities created by their sharings in this new form of the Internet and perception of these sharings by other individuals may become Internet celebrities called micro celebrities. These micro celebrities called social media phenomena can reach numerous followers with their sharings and communicate with them.

Micro celebrities who have so many followers on the Internet are among the preferred "sources" in marketing industry today due to their large number of followers and being regarded as opinion leaders by their followers and are frequently used in online advertisements.

The analysis performed in the study to determine if there is a difference between the credibility of the phenomena for participants and their attitude toward advertising by gender, it is seen that only the attractiveness dimension shows a significant difference by gender. It is seen that females assess the phenomena more positively on attractiveness dimension as they assess them well-dressed, elegant, beautiful/handsome etc.

In addition, the analysis performed in the study on the impact of the approach of individuals to credibility of the phenomena on their attitude toward advertising has concluded that only the 
attractiveness dimension of the credibility of the phenomena is influential on the attitude toward advertising. Accordingly, it can be said that the individuals who find the phenomena they follow on social media well-dressed, elegant, beautiful/handsome may have a more positive attitude toward advertising.

Therefore, it is important for the businesses, which work with the phenomena to introduce their products and brands to prefer those who give trust to target audiences and perceived as experts in their subjects and particularly the ones who would be regarded attractive.

\section{References}

[1] Ameline, D. \& Y-Q Zhu. (2016). Investigating Effectiveness of Source Credibility Elements on Social Commerce Endorsement: The Case of Instagram Indonesia, PACIS 2016 Proceedings.

[2] Bilgici Oğuz, C. \& Atasoy Aktaş, A. D. (2018). Selfie Paylaşma Sürecine Etkide Bulunan Motivasyonlar Üzerine Bir İnceleme, e:Kurgu Anadolu Üniversitesi İletişim Bilimleri Fakültesi Uluslararası Hakemli Dergisi, Cilt:26 Sayı:3, 82-100.

[3] Bowen,E. K. \& Starr, M. K. (1994). Basic Statistics For Business and Economics, McGraw Hill.

[4] Bregman, S. (2014). It's a Social World, (Eds.) S. Bregman ve K. E. Watkins, Best Practices for Transportation Agency Use of Social Media, (ss.1-26), Boca Raton FL: CRC Press.

[5] Brown, J., Broderick, A.J. \& Lee, N. (2007). Word of Mouth Communication within Online Communities: Conceptualizing the Online Social Network, Journal of Interactive Marketing, Vol.21 No.3., 1-20.

[6] Cakim, I. M. (2010). Implementing Word of Mouth Marketing: Online Strategies to Identify Influencers, Craft Stories, and Draw Customers, New Jersey: John Wiley \& Sons.

[7] Charlesworth, A. (2015). An Introduction to Social Media Marketing, New York: Routledge.

[8] Cheung Christy M.K., Lee Matthew K.O \& Rabjohn Neil (2008). The impact of electronic wordof-mouth: The adoption of online opinions in online customer communities, Internet Research, Vol.18 Issue.3, 229-247.

[9] Coles, L. (2015). Marketing with Social Media: 10 Easy Steps to Success for Business, Australia: John Wiley\& Sons.

[10] Deckers, E. \& Lacy, K. (2010). Branding Yourself: How to Use Social Media to Invent of Reinvent Yourself, USA:QUE.

[11] Driessens, O. (2016). The Democratization of Celebrity: Mediatization, Promotion, and the Body, (Eds.) P. David Marshall and Sean Redmond, A Companion to Celebrity, UK:Wiley Blackwell, 371-384.

[12] Freberg, K., Graham,K., McGaughey, K. \& Freberg, L.A. (2011). Who Are the Social Media Influencers? A Study of Public Perceptions of Personality, Public Relations Review, 37 (1), 90-92.

[13] Gao, L. (2005). Bilinguals' Creativity in the Use of English in China's Advertising, Proceedings of the 4th International Symposium on Bilingualism, ed. James Cohen, Kara T. McAlister, Kellie Rolstad, and Jeff MacSwan, 827-837, Somerville, MA: Cascadilla Press.

[14] Giddens, A. (1991) Modernity and Self-Identity: Self and Society in the Late Modern Age, Cambridge: Polity.

[15] Goffman E. (1956) The Presentation of Self in Everyday Life, Edinburg, University of Edinburgh Social Sciences Research Centre.

[16] Good, K.D. (2012). From scrapbook to Facebook: A history of personal media assemblage and archives, New Media \& Society, 15(4), 557-573.

[17] Harmon, R.R. \& Coney. K.A. (1982). The Persuasive Effects of Source Credibility in Buy and Lease Situations, Journal of Marketing Research, Vol. XIX, 255-260.

[18] Hearn, A. (2008). Meat, Mask, Burden' Probing the contours of the branded 'self', Journal of Consumer Culture, Vol. 8(2), 197-217.

[19] Hearn, A. \& Schoenhoff, S. (2016). From Celebrity to Influencer: Tracing the Diffusion of Celebrity Value across the Data Stream, (Eds.) P. David Marshall \& Sean Redmond, A Companion to Celebrity, UK:Wiley Blackwell, 194-212. 
[20] Hovland, C.I., Janis, I.L. \& Kelley, H.H. (1953). Communication and Persuasion, New Haven, $\mathrm{Cl}$ : Yale University Press.

[21] Jaakonmäki, R., Müller, O. \& Brocke, J.V. (2017). The Impact of Content, Context, and Creator on User Engagement in Social Media Marketing, Proceedings of the 50th Hawaii International Conference on System Sciences, 1152- 1160.

[22] Jansson- Boyd, C. V. (2010). Consumer Psychology, New York: McGraw-Hill.

[23] Khamis, S., Ang, L. \& Welling, R. (2017). Self-branding, "micro-celebrity" and the rise of social media influencers, Celebrity Studies, 8(2), 191-208.

[24] Kim, S., Haley, E. \& Koo, G.-Y. (2009). Comparison of the Paths From Consumer Involvement Types To Ad Responses Between Corporate Advertising And Product Advertisin. Advertising, Journal of Advertising, 38: (3), 67-80.

[25] Kline, R.B. (2011). Principles and Practice of Structural Equation Modeling, New York: Guilford Press.

[26] La Ferle, C. \& Choi, S.M. (2005). The Importance of Perceived Endorser Credibility in South Korean Advertising, Journal of Current Issues and Research in Advertising, Volume 27, Number 2, 67-81.

[27] Lee, Y-J., Haley, E. \& K. Yang. (2013). The mediating role of attitude towards values advocacy ads in evaluating issue support behaviour and purchase intention. International Journal of Advertising, 32(2), 233-253.

[28] Lee, Y.H. (2000). Manipulating Ad Message Involvement through Information Expectancy: Effects on Attitude Evaluation and Confidence, Journal of Advertising, 29:2, 29-43.

[29] Lin, H.C., Bruning, P.F. \& Swarna, H. (2018). Using online opinion leaders to promote the hedonic and utilitarian value of products and services, Business Horizons, Volume 61, Issue 3, May-June 2018, 431-442.

[30] Lou, C. \& Yuan, S. (2019). Influencer Marketing: How Message Value and Credibility Affect Consumer Trust of Branded Content on Social Media, Journal of Interactive Advertising, 19:1, 58-73.

[31] Marshall, P. David (2010) The Promotion and presentation of the self: celebrity as marker of presentational media Celebrity Studies, 1(1), 35-48.

[32] Marwick, A.E. (2013). Online Identity, (Eds.) John Hartley, Jean Burgess \& Axel Bruns, A Companion to New Media Dynamics, UK: Wiley Blackwell, 355-364.

[33] Marwick, A.E. (2013). Status Update: Celebrity, Publicity, and Branding in the Social Media Age, London: Yale University Press.

[34] McCroskey, J. C. \& Young, T.J. (1981). Ethos and Credibility: The Construct and Its Measurement After Three Decades, Central States Speech Journal, 32, 24-34.

[35] Mikuláš, P. \& Chalányová, O. (2017). Microcelebrity and Digital Media, perspektywy kultury/ perspectives on culture, numer 18 (3/2017), 67-77.

[36] Nelson, M.R., Keum, H. \& R.A. Yaros. (2004). Advertainment or Adcreep Game Players' Attitudes Toward Advertising and Product Placements in Computer Games. Journal of Interactive Advertising, 5(1), 3-21.

[37] Nisbet, M. C. \& Kotcher, J. E. (2009). A Two-Step Flow of Influence? Opinion-Leader Campaigns on Climate Change. Science Communication, 30(3), 328- 354.

[38] Ohanian, R. (1990). Construction and Validation of a Scale to Measure Celebrity Endorsers' Perceived Expertise, Trustworthiness, and Attractiveness, Journal of Advertising. 19(3), 39-52.

[39] Pikas, B., Schied, R. \& Pikas, A. (2012). Assessing the Qualities of Athlete Endorsers: A Study of Consumer Preferences for the 3 Qualities of Sports Endorsers Attractiveness, Trustworthiness, Expertise, Journal of Marketing Development and Competitiveness vol. 6(3).

[40] Priester, J.R. \& Petty, R.E. (2003). The Influence of Spokesperson Trustworthiness on Message Elaboration, Attitude Strength, and Advertising Effectiveness, Journal of Consumer Psychology, 13(4), 408-421.

[41] Schiffman, L. G., Kanuk, L. I. \& H. Hansen. (2011). Consumer Behaviour. England: Pearson.

[42] Schindler, R.M. \& Bickart, B. (2005). Published Word of Mouth: Referable, ConsumerGenerated Information on the Internet, (Eds.) Haugtvedt, C.P., Machleit, K.A. \& Richard F. Yalch, Online Consumer Psychology: Understanding and Influencing Consumer Behaviour in the Virtual World, New Jersey: LEA, pp.35-62. 
[43] Senft, T.M. (2008). Camgirls: celebrity and community in the age of social networks, NewYork:Peterlang.

[44] Senft, T.M. (2013). Microcelebrity and the Branded Self, (Eds.) John Hartley, Jean Burgess, \& Axel Bruns, A Companion to New Media Dynamics, UK: Wiley Blackwell, 346-354.

[45] Shimp, T.A. (2007). Advertising, Promotion and Other Aspects of Integrated Marketing Communications, 7th Ed. USA: Thomson Higher Education.

[46] Solomon, M., Bamossy, G., Askegaard, S. \& Hogg, M. K. (2013). Consumer Behaviour - A European Perspective 5th Ed. England: Pearson.

[47] Thoumrungroje, A. (2014). The Influence of Social Media Intensity and EWOM on Conspicuous Consumption, Procedia - Social and Behavioral Sciences 148, 7-15.

[48] Thurau, T. H., Gwinner, K. P. \& Gremler, D. D. (2002). Understanding Relationship Marketing Outcomes: An Integration of Relational Benefits and Relationship Quality. Journal of Service Research. 4(3), 230-247.

[49] White, Connie M. (2012). Social Media, Crisis Communication, and Emergency Management: Leveraging Web 2.0 Technologies, CRC Press. 